\title{
Re-bordering of the Hungarian South: Geopolitics of the Hungarian border fence
}

\author{
Norbert PAP ${ }^{1}$ and PÉTER REMÉNYI ${ }^{1}$
}

\begin{abstract}
The Hungarian borders have been at the centre of political and social discourse since the $20^{\text {th }}$ century. Subject to whichever government dominated at a given time, border policies strengthened and disappeared frequently. During the summer and autumn of 2015, a fence was constructed in effort to discourage migration at the southern borders of Hungary. Building on collective social memory which links Hungary's southern borders with divisionary actions, the government organised a campaign effective in convincing voters that more aggressive border control measures should be enacted. Opposition parties had no effective tools to counter the government's actions; thus, popular support for the government increased significantly. This paper examines how the attention and resources concentrated on the southern borders do not directly correspond to purported objectives. In fact, this paper argues that the issues related to securing the southern border of Hungary are merely used as political resources to achieve domestic political- and power-related goals. Taking into account specific international trends of border research, this work aims to illustrate how the border itself (more concisely, the policy of strengthening the southern border) became a political resource, through the remarkably efficient communications campaign of the ruling Hungarian government party.
\end{abstract}

Keywords: bordering, borderwork, debordering, re-bordering, migration crisis, Balkans

\section{Introduction}

In the summer and autumn of 2015, a fence was constructed at the southern borders of Hungary in order to halt migration. Up until earlier that year, public attitudes toward refugees reflected the sentiment of Europe as a whole: cautiously sympathetic. Non-governmental organisations and churches provided support for people who were arriving primarily from the Middle East. However, the Fidesz-KDNP2 government organised a campaign in the early months of that year, resulting in the change of political attitude which garnered attention throughout Eu-

\footnotetext{
${ }^{1}$ Department of Political Geography, Development and Regional Studies, Institute of Geography, University of Pécs, H-7624 Pécs, Ifjúság út 6. E-mails: pnorbert@ gamma.ttk.pte.hu, remko@gamma.ttk.pte.hu

${ }^{2}$ Fidesz (Fidesz - Hungarian Civic Alliance) is a national conservative centre-right political party which in coalition with KDNP (Christian Democratic People's Party) has been governing the country since 2010 .
}

rope. The Hungarian campaign to protect the country was extremely efficient in earning the support of both pro-government and opposition voters. Jobbik ${ }^{3}$ attempted to outbid the government, whereas left-wing parties avoided taking part in the dispute. Although minor liberal parties opposed the campaign, they were unable to significantly increase their support among voters. The Hungarian example had a powerful impact in East Central Europe, particularly among the Visegrád Four countries. In developed Western democracies (particularly Western Europe), the campaign and subsequent shift of public opinion earned attention and support only among radical, populist and antiestablishment parties and their voters.

This paper aims to examine all these phenomena according to the theoretical framework of border studies, a field gaining promi-

\footnotetext{
${ }^{3}$ Jobbik - Movement for a Better Hungary is a radical nationalist party established in 2003. Jobbik is the leading opposition party in Hungary.
} 
nence around the last turn of the century which highlights the social construction, nature, and dynamism of the border through the complex evaluation thereof (including O'DowD, L. 2002; van Houtum, H. and van Naerssen, T. 2002; Kolossov, V. 2005; Newman, D. 2006a,b, 2011; Scott, J.W. and van Houtum, H. 2009; PaAsi, A. 2011; van Houtum, H. 2011).

This paper argues that the perception of borders (by the governing political elite, and thus of society as well) changed after 2015 as a result of conscious political decisions and their widespread communication and dissemination by the government. The protection of the southern borders (and reinforcing the need to be protected) serves to other those who might otherwise come across, thus, threatening the national identity of Hungarians inside Hungary. By increasing attention focused on the borders through the physical strengthening of the borders and controlling discourse, political profit can be gained. This became a dominant element of identity policy in Hungary at the centre of public debates and discourses; furthermore, the narrative reinforces the belief that "Hungary has been the bastion of Europe for a thousand years." Meanwhile, the political opposition has no effective answers, and thus the national borders have become political resources for the parties in power.

This paper intends to outline the shifting political actions of Hungarian (primarily, but not exclusively) political elites in regard to Hungarian borders since the $20^{\text {th }}$ century, with particular focus on changes taking place after 2015. We argue that borders have always been an important subject of $20^{\text {th }}$ century Hungarian politics as political objectives (e.g. revision) or the means of achieving such objectives (e.g. Iron Curtain, cross-border cooperation). Furthermore, this paper also shows that the primary role of the southern borders has always been protection, ensuring a high degree of division. Finally, the paper also evaluates how the current Hungarian governing elite uses borders as resources to reach their domestic political goals in the course of competition between parties.
Regarding borders as a resource is not a new approach (O'Dowd, L. 2002; BALOGH, P. 2014, SoHn, C. 2014); however, in most cases the resource in question is used along the border (through cross-border activities) and the nature of each territory divided by the border characterize the resource (e.g. legal/illegal flows, cooperation, position). However, in the Hungarian case, using political discourse and building on society's existing assumptions and ideas through identity-building, the border becomes a resource used for an objective independent from the borders (i.e., power) and territorially not linked to them.

\section{Literature review}

The evaluation of national borders has seen its renaissance over the last few decades (O'Dowd, L. 2002; Newman, D. 2011; PaAsi, A. 2011; LAINE, J.P. 2016). This can be primarily attributed to rapidly changing activities and subsequent impacts related to borders at both the global and the local level. Firstly, the rapid pace of globalisation, particularly since the early 1990s, has made borders increasingly insignificant in the creation of a "world without borders." This includes the disassembly of traditional member-state borders, establishment of cross-border co-operations in the framework of the European integration (O'DowD, L. 2002; Sсотт, J.W. 2011), the creation of institutions and networks less dependent on geographical locations, and the emergence of sophisticated forms of overcoming distance. Secondly, de facto or de jure changes of borders took place after the fall of the bipolar world generating tensions and sensitive geopolitical situations (e.g. Kosovo, Kaliningrad). As a reaction to the security challenges of increasing international migration and global terrorism in the early 2000s, many developed countries have introduced stricter border control measures through legal, institutional, physical or other types of obstacles. Thus, borders have been put at the forefront of politics, public discourse and scientific interest (with both negative and positive connotations). 
Due to the complexity of border issues and how they affect societies, researchers from different academic backgrounds examine borders (Newman, D. 2006a), applying different, often interdisciplinary tools to evaluate their characteristics and functions. The group of researchers explicitly considering themselves "border research/study professionals" has emerged and expanded, using the aforementioned interdisciplinary and critical approach.

In addition, research works which used to focus mostly on national (and to a lesser extent subnational) administrative borders have become extremely diversified. Nowadays, the representatives of border studies view each segment of society as a range of borders that divide different groups of people (according to citizenship, ethnicity, assets, caste, job position, etc.) based on the constructed us-them distinction which strengthens group identity (either consciously or not). According to van Houtum, $\mathrm{H}$. and van Naerssen, T. (2002), some regional differences are caused by the established borders themselves, and the process of bordering creates a certain type of territorial order inwards (ordering) and causes exclusion and distinction outwards (othering).

Today, most representatives of border studies accept that the world is not progressing toward a borderless world despite the impact of globalisation, the significance of classic political borders does not fade, and the importance of social borders continuously increases (Newman, D. 2006a; PaAsi, A. 2011). However, experts also accept that borders are constantly transforming and becoming more complex while other functions remain constant (O'Dowd, L. 2002; BALOGH, P. 2014). In accordance with the approach of critical (political) geography, borders are increasingly considered social constructs (Newman, D. and PAASI, A. 1998; Newman, D. 2006a; van Houtum, H. 2011) where borders are modified continuously by the discourses and actions of various actors. In addition, debordering and re-bordering occur simultaneously and continuously, through the discourses of different interest groups.
In this paper, bordering (re- and de-bordering) is used to refer to efforts aiming to change the significance of borders which are not exclusively performed by those in power and do not exclusively mean official policies. Recently, the concept of bordering has gained a wider meaning; the creation of borders based on territorial social characteristics has become its most important aspect, in which the media, economy, ideologies, differing identities, shared values, and individual decisions are also included. However, in East Central Europe elites in power remain the most important actors of bordering, thus, we focus here on their activity.

In addition to theoretical approaches, case studies focusing on specific border sections are also important elements of the growing body of literature. As border studies are explicitly such a field of research where local specificities and contexts have a significant role, most researchers do not believe that a "final border theory" can be constructed (PAAsI, A. 2011). While conceptualisations are possible, some argue that generalised border narratives conceal more than they show (LAINE, J.P. 2016) and, thus, the operation of borders should be understood through a large number of case studies. This paper supports this argument; we intend to examine the specific discourses surrounding the southern borders of Hungary and draw related and general conclusions for other border sections as well. Although this work focuses on Hungary, we are convinced that this is a global issue since efforts to strengthen borders are increasingly on the agenda all over Europe, America, and Asia. Therefore, we expect that discourse and disputes related to borders will escalate in the future, especially in relation to the US-Mexican border, the internal and external borders of the EU, as well as borders in the Middle East and Southeast Asia. From a global perspective, the discourse surrounding Hungary's border issues are arguably relevant.

The number of Hungarian publications focusing on border issues has been growing steadily. After World War I, academic works 
focusing on the issue of borders gained prominence as the Treaty of Trianon significantly reorganised the territory of Hungary (e.g. Olay, F. 1930). During this period, Hungarian research primarily sought territorial revision (Hajdú, Z. 2008). When the Communists seized power, the examination of borders became a political/military issue; aspects of scientific accuracy could not prevail and (political) geography was restricted to examining the new state territory (Hajdú, Z. 2008). During the 1980s research increased in the field which progressed further after the transition to democracy. The Hungarian academic literature from this period is also unique: in Western scientific works a critical approach appeared in the research during the 1990s and borders were seen as social constructs rather than spatial lines of division; however, in Hungary the classic geographical approach remained dominant (Timár, J. 2007).

This type of research focusing on crossborder cooperation dominated the field and became rather unique to the Hungarian situation; due to the large number of Hungarians living outside of the Hungarian borders, cross-border cooperation has both economic and national policy implications. Authors of this paper discussed several aspects of this issue in previous publications (see PAP, N. et al. 2014, GLied, V. and PAP, N. 2017; PAP, N. and Glied, V. 2017a,b).

\section{Research methods}

During our research we monitored the communications regarding strengthening and protecting borders using the method of political discourse analysis. We analysed the messages and channels used by parties and politicians, political discourse and the construction of symbolic realities. We relied on the theory of Edelman, M. (1967) who discussed the articulation of abstract terms and meanings, such as the use of language and symbols.

The dominance of texts in politics is evident and as Bourdieu, P. (1991) explained, politics produces speeches rather than institutions.
According to OAKESHOTT, M. (1991), politics are three quarters text; one of the founding fathers of empirical political science, LAsswell, $\mathrm{H}$. and his associates (1949) conducted extensive research regarding the language of politics. However, discursivity is more complex than linguistic analysis since the entire reality of politics is generated and modified in a public process of creating interpretation, which is significantly influenced by the channel between the sender and the receiver.

Swartz, D.L. (2013) further developed this idea, arguing that political symbolism relaxes the rigidity of politics and finds links between the different levels of political socialisation. Based on the work of BurKe, K. (1969), we sought insight through distinguishing between politically active (government), politically passive (opposition) and passive observer (society) groups, including their discourse in a historical/political narrative. This paper examines the geopolitical utterances of the leading politicians of major Hungarian parties (Viktor Orbán, the chairman of Fidesz, and Gábor Vona, the chair of Jobbik) and the text of the 2015-2016 Hungarian campaigns on borders, "others" and "internal order".

\section{Changing perceptions of the Hungarian borders}

In Hungary, national borders have always played a major role in public discourse due to historical and identity-related reasons; the independent state and its divisive borders are extremely important institutions. Early Magyar tribes arrived from Asia to Europe and this has historically served to separate Hungary from its neighbours as the "odd one out" (i.e., no precise connections to Indo-European languages or ancestry in the region). (HARDI, T. et al. 2009).

The territorial consequences of the Trianon Peace Treaty which ended World War I highlighted this perception of the borders, a central element of Hungarian public dis-

\footnotetext{
${ }^{4} \mathrm{~A}$ more exhaustive analysis of this issue can be found in PAp, N. and Glied, V. (2017a) and Glied, V. and PAP, N. (2017)
} 
course (shifting depending on the dominant political directions) since the early $20^{\text {th }}$ century. During the interwar period, clear and unilateral debordering was the aim of the Hungarian public discourse and politics which manifested in efforts taken to enable territorial revisions. To different extents, territorial claims were articulated against each of the neighbouring states, leading to unilateral efforts to modify the borders. This was not only true at the level of international and national politics, but also at the levels of everyday life, education, and ordinary routines (public, private and church). The border revisions achieved with the assistance of Nazi Germany prior to and during World War II were short-lived and the Paris Peace Treaties (1947) annulled all of them.

During state-socialism unilateral re-bordering was the most typical approach. Several border sections were strengthened by technical barriers, filtering and blocking both outward and inward access, and the communist regime systematically increased isolation. The most well-known example for that is the Iron Curtain, separating the West and the East at the western borders of Hungary. To a similar extent, the southern border of Hungary, shared with Tito's Yugoslavia (which had been expelled from the communist community), was also militarised from the late 1940s to the mid-1950s. The Hungarian Maginot Line was constructed here in the late 1940s to prepare for armed conflict between Yugoslavia and the Warsaw Pact countries (Horváth, I. and Kiss, J. 2008). Border control became stricter, and in lieu of the Interior Ministry, the State Protection Authority (ÁVH) took control of the border zone. In general, the period of state-socialism increased the dividing role of borders (in a military, ideological, and economic sense), and not only toward the West, but with the "friendly" socialist countries as well (HAJdú, Z. 2008).

After the change of regime in Central and Eastern European countries, multilateral debordering was initiated in accordance with liberal European values. At this time, experts began documenting the development of a "borderless world" created by globalisation and European integration which had spread to East Central Europe. The ending of the Cold War, the subsequent opening of borders and the restoration of the freedom to travel became symbols of liberalisation. In addition, several city partnership agreements and cross-border institutional cooperations emerged, and the construction of the missing cross-border infrastructure was initiated. On the path towards EU accession Hungary and its neighbours had interest in deconstructing borders at both international and local levels. This was generously supported by the integration institutions in accordance with the vision that Europe would become a "Europe of regions" instead of a "Europe of nations" (O'Dowd, L. 2002). Despite minor setbacks, the aforementioned processes dominated Hungary right until the 2010s. Interestingly, the globally significant events of 11 September had no major impacts on border discourses.

However, the new government taking office in Hungary in 2010 enacted many changes which shifted the approach of the political elite toward borders through measures such as passportization, support of symbolic causes (e.g. the flag of Szeklerland) and functional actions (e.g. foreign political campaigns, investing in the economic zone of the Carpathian Basin, cross-border financial supports of various national goals). ${ }^{5}$ This led to protests from

\footnotetext{
${ }^{5}$ Pursuant to Section 3 of Act XLV of 2010: "all members and communities of the Hungarian nation, subjected to the jurisdiction of other states, belong to the single Hungarian nation whose cross-border cohesion is a reality and, at the same time, a defining element of the personal and collective identity of Hungarians". The double citizenship regime (2010) allows ethnic Hungarians who are citizens of a neighbouring state to obtain Hungarian citizenship easily, which is seen as one of the most important means to reach the virtual reunification of the nation. The flag of Szeklerland, a historical region in central Romania with predominant ethnic Hungarian population, has been flying over Hungarian parliament since 2013 despite being the focus of several debates between Hungary (or ethnic Hungarians of Romania) and Romania. The Wekerle plan of the Ministry of National Economy aims (among others)to strengthen the positions of Hungarian enterprises in the Carpathian basin, etc.
} 
the neighbouring countries in many cases which did not deter the Hungarian government to further defining their borders. In this period, a new approach toward borders appeared: national borders were assigned political roles and tasks related to domestic politics, power and identity. Hungarian border politics had previously been typically practical in its approach; measures of revision or militarisation of borders and debordering had been the subject of politics and problem-solving political issues. However, after 2010 the border became a tool and a resource to achieve goals less related to borders themselves.

After 2015, the European migration crisis became the new international challenge and brought about political changes which also affected borders. The perception of borders shifted in political narratives, the southern border became the front line, protecting not only Hungary, but Europe and the entire Western World. Unilateral re-bordering was launched, with open protests from the affected neighbours in many cases. However, with regard to the other borders, virtualisation remain the dominant approach, at least on behalf of the Hungarian party. In addition, the typical characteristic of politics related to borders after 2010 is still true: border protection is not of concern due to problems related to the borders themselves, but due to goals independent of the borders; border issues have become a political resource.

It is important to emphasise that members of the society do not view all of Hungary's borders identically. The social values, ideas and associations related to specific border sections (strategic directions) are historically quite different. Hungary's western and northern border regions are regarded as being occupied by groups with similar cultures (western Christianity), Europaism, traditional modernisation and innovation (German regions, shopping and tourism, guest workers, investors) and shared fates (Poland). Historically, these groups have had positive connections with Hungarian people and their traditions became Hungarian traditions and vice versa. Despite military threats (the age of the Árpád Dynasty in the $11-13^{\text {th }}$ centuries, 1703-1711, 1848-1849 and in 1944) and rivalries (e.g. Poles in the Middle Ages, the Czechs and the Slovaks in the $20^{\text {th }}$ century), the traditional Hungarian collective memory about the western and northern neighbours is positive. However, the social stereotypes associated with the eastern borders are more negative, attributed to the vicinity of the Russian sphere of influence, the perception of backwardness. Although the border of Romania and Hungary is eastern in geographical sense, the related attitudes are more similar to those toward the southern Balkan neighbours.

In regard to the southern border, according to the 1993 and 2000 surveys of Gallup, twothirds of Hungarians (71\% in 2000) agree with the following statement: Hungary has been the bastion protecting the West for a thousand years, and they have not been grateful (even now) (SzÁrAz, O. 2012). Thus, the role of the "bastion" of the West, Europe or Christianity is still a living concept in the minds of many Hungarians.

In this paper we focus on the issue of how this "bastion" role applies to the southern borders of Hungary, where they also function as the boundary towards the Balkans. The Hungarian perception of this border is centred around the narrative of protection from the inevitable clash of cultures. Table 1 explores how different political events affected the functions of Hungary's southern borders.

The current southern border of Hungary is a result of the Trianon Peace Treaty of 1920. Throughout the $20^{\text {th }}$ century the Hungarian-Serbian, Hungarian-Croatian and Hungarian-Slovenian borders changed on multiple occasions, however, they were reverted back to the 1920 division.

The majority of the southern borders of Hungary is linked to (and divided from) territories of the (Romanian, Serbian and Croatian) nation-states which are considered by the Hungarian public as the "Balkans". This Balkan identity serves to other the nation-states south of Hungary as being "different" than the Hungarian state. From a religious point of view, this difference initially meant Islam (for centuries, the Ottoman 


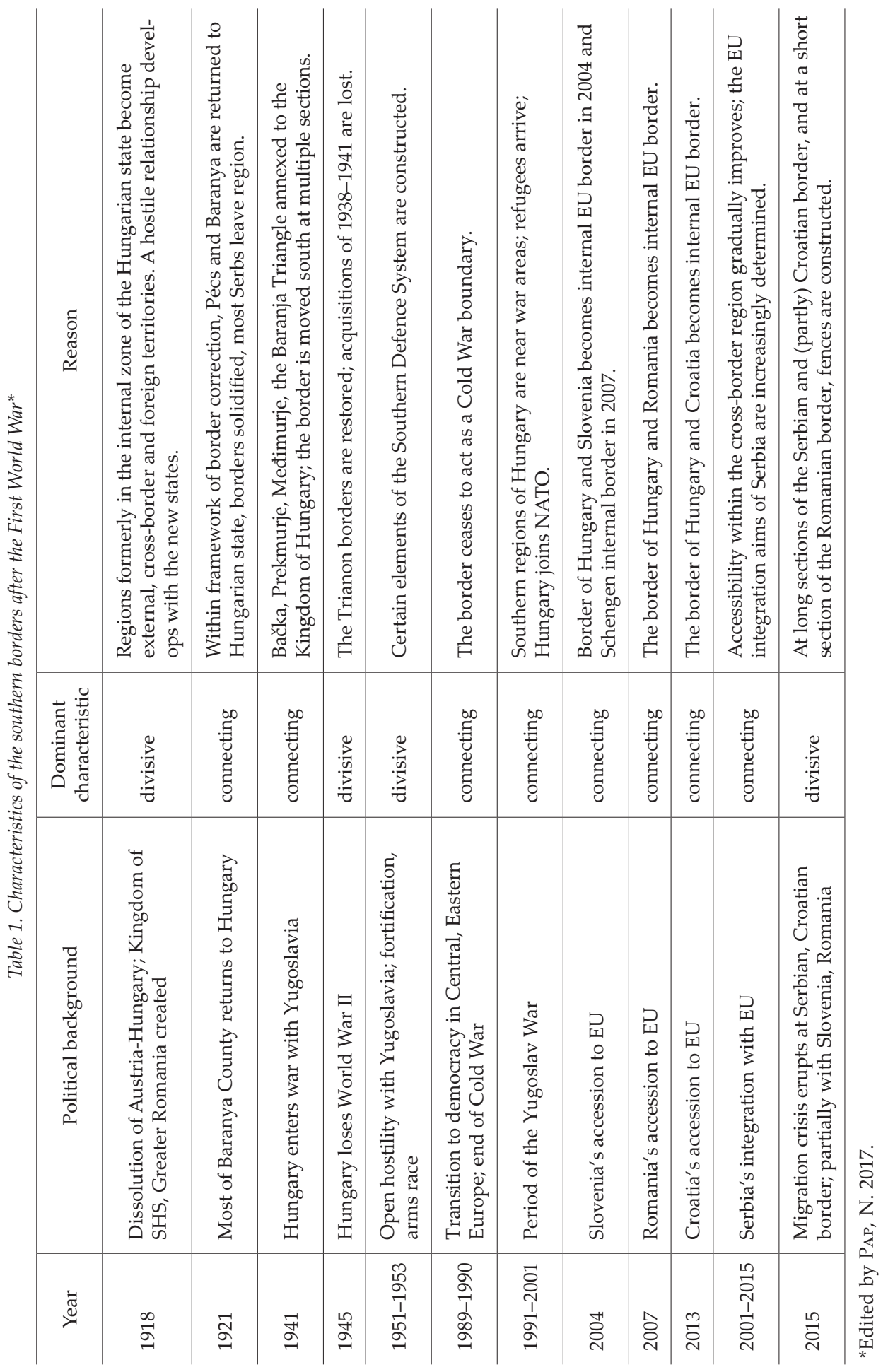


Empire occupied the other side of the border), then Orthodoxy (regarding Serbia and Romania), against which Hungarians and Hungary served as the "bastion of Europe" for "a thousand years." In addition to these religious associations based on historical traditions, the southern border is also known for being lined with threat and protections (border fortifications and the remains of Ottoman conquest still survive here, as well as the Militärgrenze i.e. military frontier established by the Habsburgs in the $18-19^{\text {th }}$ century). Indeed, this is the site of the anti-Hungarian Serbian movements of the freedom fights against the Habsburgs and the Yugoslav wars of the 1990s and has historically been the most unstable border section of Hungary (RónAI, A. 1945). It is apparent that the narrative created by the Hungarian government effectively relied on this as well (Figure 1). gration particularly dangerous. ${ }^{6}$ There are no major immigrant groups in Hungary, religious citizens typically follow a Christian denomination, and cultural identity is based on Judeo-Christian cultural cornerstones.

After the change of regime, numerous studies examined xenophobia and discrimination in Hungary. TÁRKI Social Research Institute has systematically studied xenophobia and attitudes of Hungarians toward foreigners and minorities since 1992. Based on these surveys it can be said that almost half of all Hungarians (two-thirds after 2015) expressed prejudice towards immigrants from third-world (i.e. less developed) countries. The higher rate of xenophobia compared to other countries ${ }^{7}$ in the region can be partly attributed to problems caused by co-existence with the Roma minority. In addition, people project problems of Western Europe to their

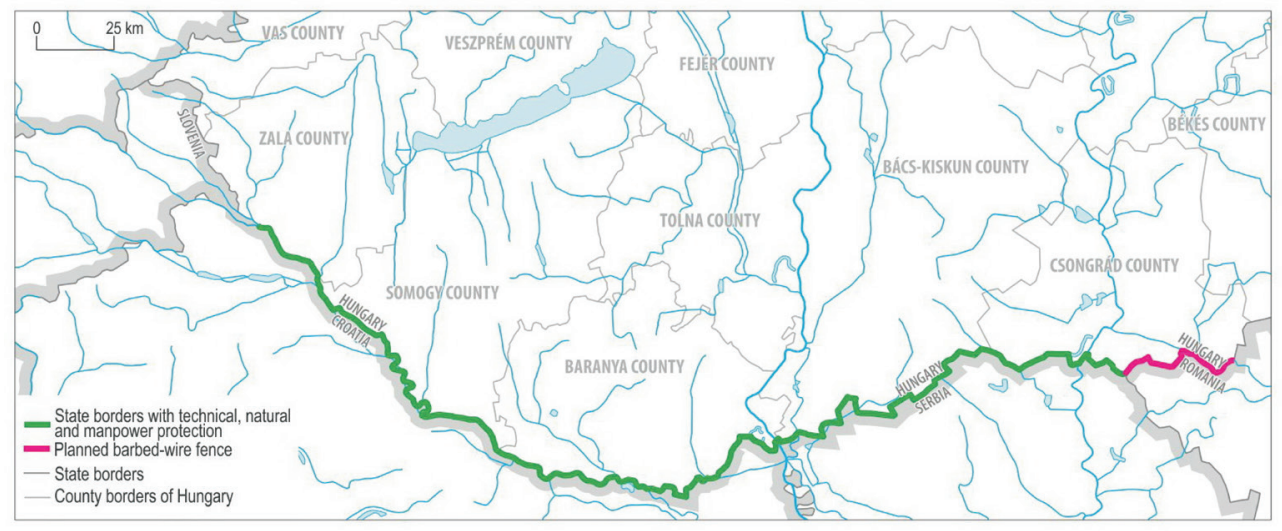

Fig. 1. Barriers along the southern border of Hungary in 2015 (ed. by PAP, N., graphics by SimoN, B.)

\section{The migration crisis and the importance of borders}

In Central and Eastern Europe immigration did not cause problems that would have affected the everyday lives of people until very recently (Kocsis, K. et al. 2016). Several researchers confirmed that until 2015 the citizens of Hungary did not consider immi-
${ }^{6}$ Poverty, fear of an uncertain future, and emigration all ranked higher in the polls than fear of immigration. However, the degree of xenophobia is extremely high in Hungary compared to other Central and Eastern European countries. This is supported by the Eurobarometer surveys - Standard Eurobarometer 82, Autumn 2014. http://ec.europa. $\mathrm{eu} /$ commfrontoffice/publicopinion/archives/eb/ eb82/eb82_anx_en.pdf

${ }^{7}$ On the eastern part of Germany see Glorius, B. 2017, on other post-socialist countries see Sík, E. et al. (2016). 
own country and the issue has been further exacerbated by the traditional approach that Hungarians - with their unique language, culture and history - are an island in Europe and must fight to protect their sovereignty.

Among the voters of Jobbik, the rate of Hungarians expressing open xenophobia is above average; however, according to surveys from 2015-2016, party preference played only a very small role in rates of xenophobia. For this reason, it can be concluded that the migrant crisis and the anti-migrant government campaign played an important role in the widespread rejection of immigrants and migrants (Simonovits, B. and Szalai, B. 2013).

Interestingly, Hungarian radical nationalists (supporters of Jobbik) are sympathetic toward followers of Islam and the largest organisation of Hungarian Muslims (Magyar Iszlám Közösség) has shown support for Jobbik. Party chairman Gábor Vona has emphasised his appreciation for Islam on numerous occasions. This phenomenon has complex cultural reasons, but is primarily attributed to the historical context of early Hungarian Turanism $^{8}$. Jobbik's pro-Muslim approach was advantageous to Fidesz who tried to use

\footnotetext{
${ }^{8}$ Regarding Islam, Hungary has a special and unique history in Europe. A minority of the Hungarians (Magyars) settling in the Carpathian Basin during the $10^{\text {th }}$ century were the followers of Islam, which was preserved as a base of royal power for centuries (PAP, N. et al. 2014). Later, in the periods between specific instances of assimilation, Muslim communities appeared. Sometimes co-existence had severe social and economic consequences, such as during the period of Ottoman occupation in the $16-17^{\text {th }}$ century. The Battle of Mohács in 1526 lead to the demise of the Kingdom of Hungary in the Middle Ages. The 150-year Turkish occupation and then the destruction of the liberation wars resulted in a changing ethnic structure in the central part of the Carpathian Basin, which is considered the primary reason for the decline of the country according to the mainstream explanations. However, Turanism, as an ideology linked to the Hungarian far-right, emphasises family and cultural ties to Turkish peoples, as well as cultural links, and it is sympathetic toward Muslims. The most significant Turanist group of our times is organised within Jobbik, which makes it clear why party leader Gábor Vona acted sympathetically toward the Muslim world on numerous occasions.
}

nationalist rhetoric to win back its earlier popularity and influence hundreds of thousands of voters who had switched to Jobbik.

The political discourse and communications emerging in relation to the $2015 \mathrm{mi}-$ grant crisis balanced on the verge of reality and semi-reality when it expressed and conveyed powerful messages (in multiple stages) to both Hungarian citizens and migrants. Initially this caused a great divide in public opinion. The main semantic element of the discourse was the idea that there existed a need to protect Hungary and its residents from the unfavourable impacts of the migrant wave and that Hungary would resist the invasion of hostile people and their culture. The word protection utilises the people's need for safety, capitalises on their instinctive fear, and legitimises the importance of preventive actions. The protection of the country and national sovereignty effectively directed the attention of people to the issue of borders and border protection. In addition, the phenomenon of social (re)bordering was also carried out by the government: it tried to construct physical borders, as well as new social ones.

\section{Discursive and physical strengthening of national borders (re-bordering)}

In order to achieve its objectives, the government had to demonstrate that a threat existed. By mixing up legal and illegal migration, as well as the categories of refugees and immigrants, the Orbán government was able to blur the social and legal lines between them (which might be considered a type of partial top-down debordering). In addition, by appropriating the word protection, the government strengthened the coherence of its own communication, since political, legal, and policing means were available to control the wave of migrants. On the other hand, opposition parties did not have any possibility for action. When the crisis erupted, they remained hesitant and did not have access to a realistic assessment of the ongoing process. 
The largest governing party, Fidesz was successful in constructing its own narrative of what was happening, in effect forcing the opposition to merely follow governmental communication after the summer of 2015. Hungarian Prime minister Viktor Orbán surprised Paris with his statement given right after the attack on the head office of the satirical magazine Charlie Hebdo in January 2015. The Hungarian premier had already emphasised protection against the dangers threatening Europe. Initially, this looked like an effort to divert attention from internal political and social problems, but later proved to be an efficient political weapon in the competition with Jobbik for popularity and the restoration of the governing party's popularity.

In summer 2015, countries of the Balkans, Central Europe, and Western Europe blamed and criticised each other for the failure of the migration policy through political statements and messages. Meanwhile, at the Keleti and Nyugati Railway Stations of Budapest, thousands of refugees demanded permission to proceed to Austria without registering in Hungary, further deepening the crisis (Photo 1 and 2) In addition to its practical function, the temporary barrier (fence) erected on the southern borders of Hungary by mid-2015 also served as metaphor in Hungarian and European public discussions.

That same summer Viktor Orbán argued that the failed politics of Western Europe cannot protect the continent from migration, and therefore, Hungary must protect its borders independently by constructing a physical barrier. ${ }^{9}$ The official government communication built on the historic concepts of "Hungary, the fortress of Christianity" and the "bastion of Europe" and the fence became a token of protection, an important concept omnipresent in Hungarian political thinking.

On 19 September, the Hungarian premier attended a meeting of the conservative German CSU party state legislature group in the Banz

\footnotetext{
${ }^{9}$ Viktor Orbán: If we do not protect our borders, several other tens of millions will come and Europe will end - In the programme " 180 perc" of Kossuth Rádió. http://www.hirado.hu/2015/09/04/hallgassaitt-eloben-a-miniszterelnoki-interjut/ (4 Sept. 2015)
}

abbey in Bavaria, where he argued that the European Union and the Schengen Agreement make Hungary a border fortress for Bavaria. As such, he asserted that Hungary is currently the protector of the southern border of Europe, and therefore he is the fortress captain.

Fortress captains are important parts of the Hungarian collective memory; all Hungarians are taught to remember the heroic resistance of fortress soldiers in the $15-17^{\text {th }}$ century who fought against the Ottoman forces despite being outnumbered. They have memorized the name János Hunyadi, the victorious protector of Belgrade; they remember the men and women defending the fortress of Eger (and their captain, István Dobó) and the sacrificial sortie of Miklós Zrínyi who held the Szigetvár fortress till his dying breath. An obvious parallel exists between the struggle of the intruding Muslim "forces" (i.e., refugees, illegal migrants) and the handful of Christian defenders (i.e., Hungarian police and army). However, combat surrounding Hungarian border fortresses historically also meant suffering. For this reason, Viktor Orbán attempted to neutralise the correlation by adding that although Hungary is not keen on the role which it has been given, Hungary must accept its duty as protector of the southern border. A billboard campaign launched in mid-September 2015 reinforced this idea with a primary message centred around the word protecting: "The people have decided: the country shall be protected". The governing political elite created this campaign in order to make the concept of protection the central element of the dominant narrative. This saw to the commencement of the strengthening of the division function of the southern borders in regard to legal aspects and human resources as well as technically and theoretically.

\section{Distinction of migrants ("othering") through strengthening social borders}

In March-April 2015, the governing political elite attempted to explain why hundreds of 


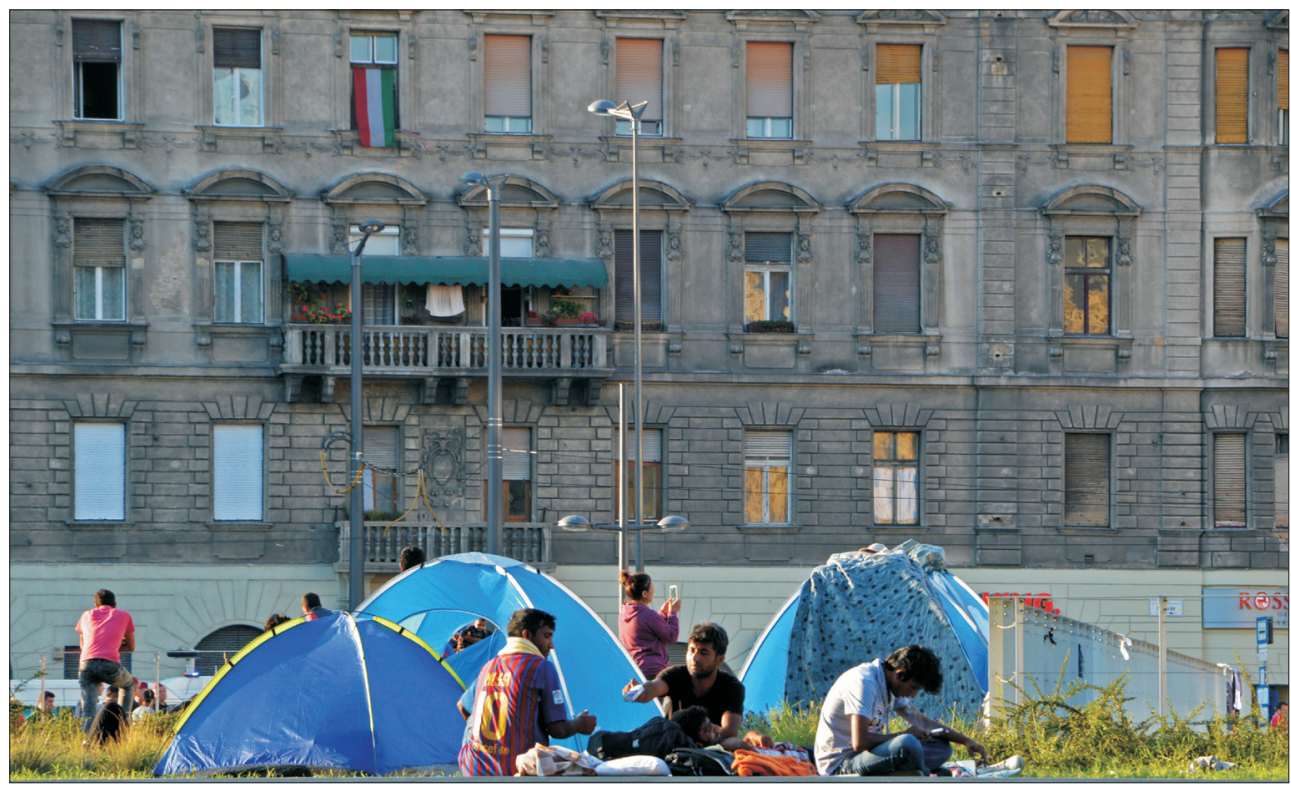

Photo 1. Migrants at the Keleti Railway Station of Budapest, September 2015 (Photo by Glied, V.)

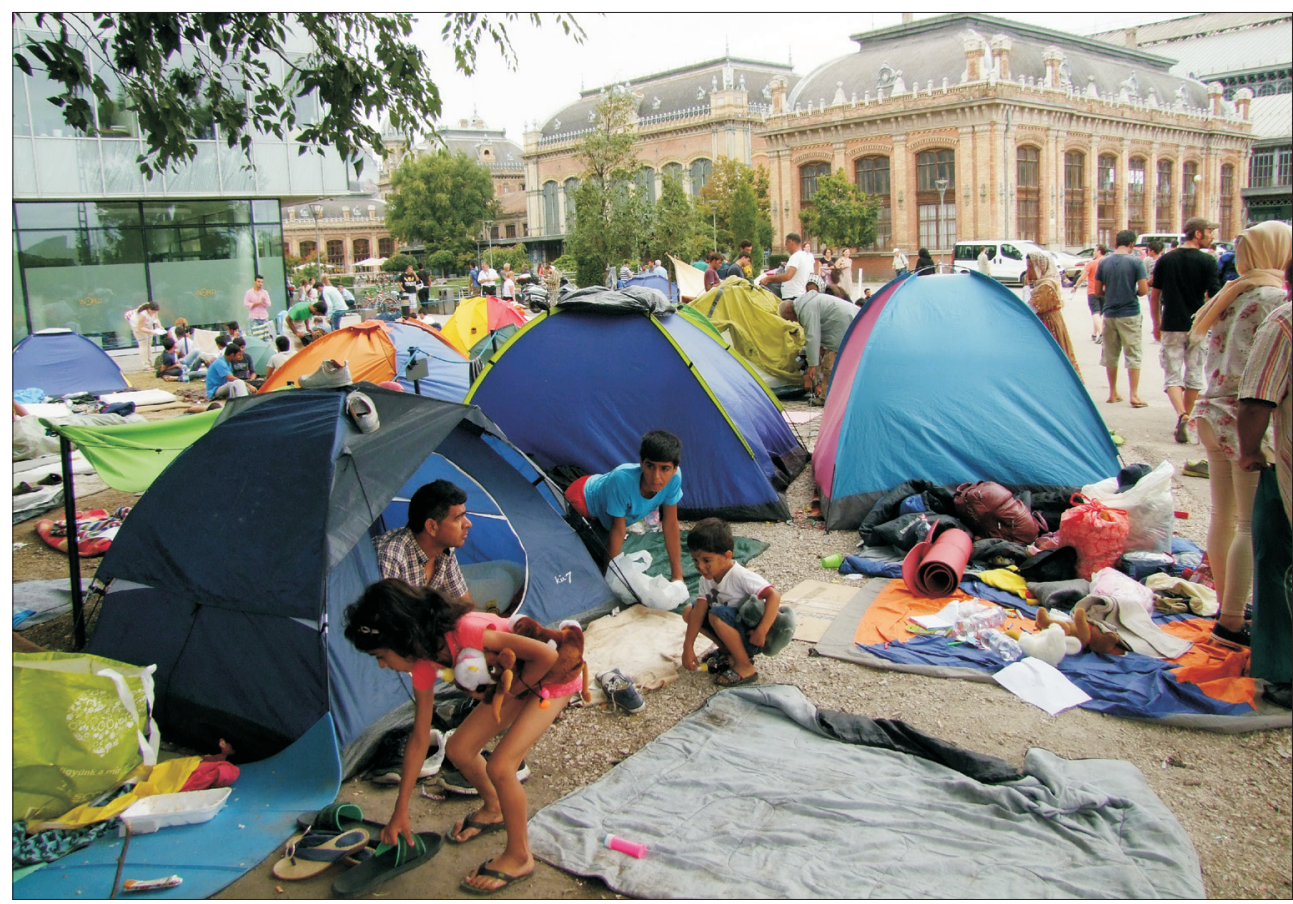

Photo 2. Migrants near the Nyugati Railway Station of Budapest, September 2015 (Photo by Konkoly Thege, G.) 
thousands of migrants with a different culture and religion had arrived to cross Hungary to Western Europe. Billboards and television commercials addressed to migrants were launched in early summer, the main message of the campaign being, "If you come to Hungary, you have to respect ...." The Hungarian public became more and more aware of the issues since previous to this they had not (and could not) have any personal experience related to the phenomenon and could have only encountered migrants themselves in very limited geographical spaces.

By early autumn 2015, the discourse had elevated to a new level and the central narrative also changed. These messages highlighted the issues of co-existence with Muslims and the failure of multiculturalism in Europe. In addition, Europe-wide questions were being raised about whether successful coexistence was possible. An extract from a book of Nobel laureate Hungarian writer Imre KeRTÉsz, published in 2014, went viral; Kertész argues that based on the liberal immigration policy of Europe, Muslims had spread, would take over and destroy Europe with their own means. ${ }^{10}$ These ideas are echoed in the book Submission, published by French writer Michel Houellebece in January 2015 proving to be highly controversial. ${ }^{11}$ Rather than a physical barrier preventing the flow of potential danger, the government's narrative centred around the highlighting and construction/strengthening of a religion-based social border. The main message pushed discourses to highlight and emphasize differences, thus, constructing the "other" which differs from the majority.

In October 2015, Lajos Kósa, head of Fidesz parliamentary group, argued that Muslim culture is so radically different from European

\footnotetext{
${ }^{10}$ Many media outlets reported on the extract of the controversial work in Hungary and abroad as well (Kertész, I. 2014).

${ }^{11}$ Published a day after the attack on Charlie Hebdo, Submission has a new approach to the issues of Islam spreading in Europe. It has become practically unavoidable in related discussions (HouellebecQ, M. 2015).
}

culture that integration is hopeless. This message countered Gábor Vona's assertion that Islam was the last hope of mankind ${ }^{12}$. By highlighting the hopelessness of integration policies, Kósa suggested that the solution underlies in stopping the migration wave, rather than dreaming of co-existence. He claims that migrants are economic immigrants, who travel to Europe in order to "occupy territory" and that the Western left sees them as future voters. ${ }^{13}$ These pro-government politicians' messages were in perfect alignment with the expectations of the majority ${ }^{14}$.

Several political conflicts could be attributed to the flow of migrants (e.g. domestic political struggles, disputes within the European Union, conflicts with Hungary's neighbours including Serbia, Croatia, Slovenia, Romania, Austria), further supporting the government's arguments. Although initially hesitant, the Hungarian society eventually adopted a negative approach to the migrant situation, represented through assumptions that migrants were dangerous and/or inferior (e.g. dirty, leave their garbage around, break laws, travel free of charge, spread diseases, harass and rape Hungarian women, take over the country).

A small number of civil organisations, politicians, and minority parties and a significant number of individuals expressed their opposition to the government's campaign, some by guerrilla actions against anti-migrant bill-

\footnotetext{
${ }^{12}$ Vona Gábor about Islam. http://www.jobbik.com/ vona_g\%C3\%A1bor_about_islam

${ }^{13}$ Interview with Lajos Kósa, the head of the Fidesz parliamentary group, in the pro-government daily Magyar Idők. http://magyaridok.hu/belfold/ remenytelen-muszlim-bevandorlok-integralasa-29803/

${ }^{14}$ While the issue of constructing the fence slightly divided the public in the summer of 2015 (60-65\% of the residents supported it on the average), by December, after the Paris terror attacks, 85 per cent of the respondents believed that the physical barrier at the border was a good decision. The communication of the governing party was successful. This is clearly reflected in the fact that the proportion of those who reject the acceptance of refugees grew to $83 \%$, and almost half of the citizens thought that Hungary was going to be affected by terror. For more on this, see BERnát, A. et al. (2015).
} 
boards and others through directly helping migrants/refugees. However, their narratives were overwhelmed by the official discourse of the government and their initiatives stayed local and, thus, invisible to the wider public who was not in direct contact with refugees (e.g. majority of people living in parts of the country away from migrant routes).

\section{Increasing othering: Enemisation}

After the Paris terror attack in early November 2015 (Bataclan), the Hungarian government went a step further. According to the Hungarian premier, the link between immigration and terrorism is undisputed because all terrorists are migrants. Furthermore, since the West is at war with Islamists in the Middle East, it is no surprise that enemies would send warriors among the arriving migrants. By allowing millions of people into Europe without identifying them, we risk increased threat of terrorism. Therefore, according to Orbán, external borders must be secured, Schengen must protected, and considering any other alternative is futile. ${ }^{15}$ Thus, the othering which had characterised the government's official stance was now being replaced by the creation of enemy scapegoats (enemisation). Now, not only were people on the other side of the social border "others", but dangerous, threatening and hostile others; the narrative had undergone militarisation.

By strengthening the anti-Muslim narrative, Fidesz-KDNP effectively exploited Jobbik's unique pro-Muslim policy. Because the radical-right party had no means to counter this, the radical nationalists began to lose the migration crisis debate and were overtaken by the centre-right governing party (slowly shifting toward the right $)^{16}$. After summer

\footnotetext{
${ }^{15}$ All terrorists are migrants. http://www.politico.eu/ article/viktor-orban-interview-terrorists-migrantseu-russia-putin-borders-schengen/

16 The $16-17^{\text {th }}$ century is the period when the two different historical narratives were born which made reaching a consensus in the issue of Muslims impossible in Hungary. The mostly
}

of 2014, voters originally supporting Fidesz who had switched to Jobbik again returned to the governing Fidesz party. Skilfully applied communications earned large political profit in the short run.

The government had managed to not only protect Hungary from terrorists, but to show the West that it had taken the wind out of the sails of the radical-right Jobbik party, as it had left no room for argument. Opposition forces remained passive, they had no proposed solutions, and thus Fidesz-KDNP was the single power that could take real action. Based on discourse analysis, this can be evaluated as significant political triumph: the governing party kept the leading role in political discourse, strengthened its positions, and polls were clearly in their favour (Figure 2).

According to the surveys of TÁRKI and Závecz Research, the level of xenophobia in Hungary had reached unprecedented heights by October 2016. By then, Arabs had replaced the gypsies as the most rejected ethnic group. 58 per cent of respondents considered themselves xenophobic, evidently a consequence of the anti-migrant political campaign which hit its peak through the anti-quota referendum of 2 October $2016 .{ }^{17}$ This referendum campaign was built upon two narratives. The first focused on blaming Brussels, and thus the liberal European elite and its "willkommenskultur", which had rendered itself de-

Catholic, pro-Vienna and pro-Habsburg faction, favouring a Western orientation instead of national independence, sees and represents the place and role of Hungary as a European/Catholic/Western "bastion". The other faction is mostly Protestant (Calvinist), pro-independence, anti-Habsburg, emphasises national sovereignty, and considers a Turkish (Muslim) alliance suitable to reach key national objectives. The latter group emphasises the importance and eastern origin of Hungarian traditions. In the political fights of the $18-19^{\text {th }}$ century both narratives regularly appear. Their modern age impact is suggested by the fact that these themes have also appeared in the communications of the politicians of Jobbik and Fidesz as well.

${ }^{17}$ Sosem látott mértékű a magyarországi idegenellenesség. (Xenophobia at an all-time height.) http://index. hu/tudomany/2016/11/17/soha_nem_latott_merteku_ az_idegenellenesseg_magyarorszagon/ 


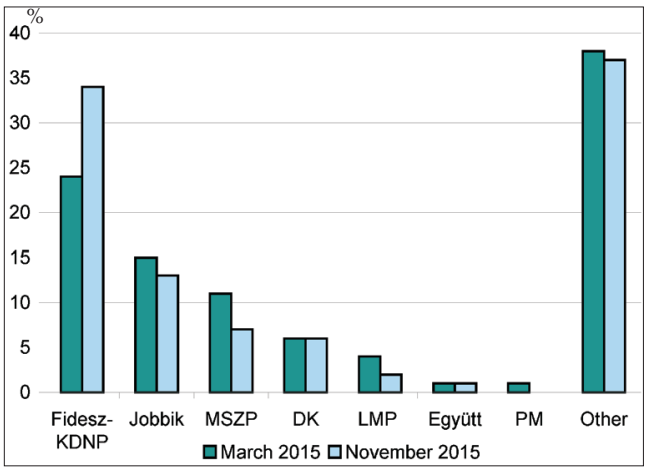

Fig. 2. Polling data on the support of major parties in Hungary, March and November 2015. (Source: Medián) *On Fidesz and Jobbik see footnotes 2 and 3. MSzP (Hungarian Socialist Party) is the leading socialdemocratic party in Hungary, governing from 1994 to 1998 and from 2002 to 2010. DK (Democratic Coalition) is a centre left party formed by secessionist politicians from MSzP in 2011, led by former PM Ferenc Gyurcsány. Együtt (Together) is a social liberal minority party formed in 2012. PM (Dialogue for Hungary) is a green liberal party founded in 2013 by secessionists from LMP. LMP (Politics can be different) is a green liberal party founded in 2009.

fenceless and unable to find effective solutions. This narrative urged voters to "send $a$ message to Brussels" that Europe might "understand" that Hungarians would pioneer efforts in forcing leading European politicians to explicitly state that their migration policies (or lack thereof) and multiculturalism had failed. Fidesz politicians asserted that their government would not carry out "dangerous relocation plans" but instead would reinforce border protection. They fought against the quota package mandated by Brussels, arguing that it would involve "significant economic, cultural and safety risks." They predicted a "catastrophe" and claimed that there are "more than 900 no-go zones in Europe". ${ }^{18}$

The second narrative aimed to reinforce the existing public attitude towards the Muslim migrants. Through a "Did you know..." campaign with questions on billboards, television, and radio commercials, the government

\footnotetext{
${ }^{18}$ http://kvota.kormany.hu/
}

emphasized the risks of migration through Hungary and promoted the fortification of the border. The campaign asserted that Hungary was on the right track, protecting the country and Europe from terrorism. The government claimed that its "...foremost reason for rejecting the relocation quota is that it would significantly destruct the security of Europe. Events of the last few months have reassured us that there is a link between immigration and terrorism." The government claimed that "protecting our communities, families, culture and everything that defines Hungary are all at stake" and "if we fail to act, we will not recognise Europe in a few decades." The government even asserted that "in Europe, terror and violence have become a part of everyday life."

The referendum was held on 2 October 2016 and the result was invalid, as less than 50 per cent of those eligible to vote participated. Despite this, the government claimed that the referendum was successful in the political sense. 3.2 million voters (98\% of referendum voters) expressed their support for the actions recommended by the government, proving that a number of Hungarians agreed with the government's stance on the migrant crisis. It is likely that the 98 per cent who voted against the quota did so due to the overwhelming anti-quota campaign efforts; moreover, the satirical Hungarian “Two-Tailed Dog Party" was also extremely successful (through guerrilla efforts) to convince others to invalidate their vote. The Hungarian Socialist Party (MSzP) also asked the voters not to vote since the powerless referendum held no meaning. ${ }^{19}$

\section{Conclusions - "Hungary, the bastion of Europe"}

The borders of Hungary have been in the focus of political and public discourse since the beginning of the $20^{\text {th }}$ century. Depending on the political regime in power, politics and policies related to borders often

\footnotetext{
${ }^{19}$ See Glied, V. and Pap, N. (2017).
} 
changed, sometimes aiming at strengthening them, sometimes to make them disappear. Actions taken regarding the borders alternated between unilateral and cooperative approaches, corresponding with changing (border-related) interests.

This changed in 2010 when borders became resources used by the governing party to achieve its goals; after 2015, these objectives were not connected to the real problems of the physical borders themselves, but primarily based on prejudices existing in society which influenced public discourse with the aim of strengthening political positions. Social memories built throughout Hungary's history continue to connect the key function of protection to the southern borders, which the official narratives can easily exploit in order to improve public approval of strengthening the border. This same narrative also asserts the Hungarian national duty of protecting borders as self-sacrificing, morally obligatory, and performed for all of Europe, thus also contributing to the approval thereof. The metaphor "bastion of Europe" has become frequently used in both Hungary and the international media, and the Hungarian government has used it to increase its own approval and support.

Hungary's Fidesz government was the first within the EU to openly call for closing the borders and to take practical steps towards international migration. However, Hungary is not the only country demanding border fortification and utilising tensions related to borders as a domestic political tool. After 11 September 2001, stricter border control regulations and the construction of a safety fence indicated that a new approach was gaining ground in the US (AcKLESON, J. 2005). During the last presidential campaign, the current president famously espoused the additional physical strengthening of the Mexican border, using the border as a resource in domestic politics, for objectives unrelated to the border itself. Similar to the southern border of Hungary, the southern border of the US also plays an important symbolic role in the life of society. It is a border created through war, exposed to migration, plagued by illegal flow, and argued to be a safety threat (whether accurate or not) (CHACón, J.A. 2010). Immigrants can be "othered" as compared to the majority US population and as such, the border can become a political resource as well.

Many European populist/right-wing parties aim to seize power through the restriction of migration and the strengthening of the protection of borders (e.g. the National Front in France, the Dutch Freedom Party). In fact, the entire European border control system serves to protect Europe and is supported by political forces and social groups. Therefore, the Hungarian case is not without predecessors, and the spread of similar solutions can be expected in the near future.

A key characteristic of the top-down bordering at the southern Hungarian border is the government-controlled discourse constantly represented as self-sacrificing for the wider community and a higher good. Thus, according to the official narrative, the government not only protects Hungary, but also Europe, the West, Christianity ... (as opposed to other border fences primarily constructed to protect national interests). Important traditions throughout Hungarian history reinforce this narrative; thus, historical parallels can be made supporting society's acceptance of a narrative constructed to strengthen Hungarian identity.

\section{REFERENCES}

Ackleson, J. 2005. Constructing security on the U.S.Mexico border. Political Geography 24. (2): 165-184.

Balogh, P. 2014. Perpetual borders: German-Polish cross-border contacts in the Szczecin area. Södertörn doctoral dissertations, 92. Stockholm, Stockholm University.

Bernát, A., Sík, E., Simonovits, B. and Szeitl, B. 2015. Attitudes towards refugees, asylum seekers and migrants. First results. Budapest, TÁRKI Social Research Institute.

Bourdieu, P. 1991. Language and symbolic power. Cambridge, Harvard University Press.

Burke, K. 1969. A rhetoric of motives. Berkeley, University of California Press.

CHAcón, J.A. 2010. The U.S.-Mexico border. International Socialist Review 73. https://isreview.org/issue/73/usmexico-border; Accessed: 04.05.2017. 
Edelman, M. 1967. The symbolic uses of politics. Chicago, University of Illinois Press.

Glied, V. and PAP, N. 2017. The "Christian fortress of Hungary" - The anatomy of the migration crisis in Hungary. In Yearbook of Polish European Studies. Ed.: GóralczyK, B., Warsaw, Centre for European Regional and Local Studies, University of Warsaw, 133-150.

GLorius, B. 2017. The challenge of diversity in rural regions: refugee reception in the German federal state of Saxony. Hungarian Geographical Bulletin 66. (2): 113-128.

HajDú, Z. 2008. A Kárpát-medence államosodási folyamatainak változásai és történeti földrajzi elemzésük (Changes in the state formation processes of the Carpathian Basin and their historical geographical analysis). Korall 9. (31): 75-100.

Hardi, T., Hajdú, Z. and Mezei, I. 2009. Határok és városok a Kárpát-medencében (Borders and cities in the Carpathian Basin). Győr-Pécs, Centre for Regional Studies, MTA.

Horváth, I. and Kiss, J. eds. 2008. A baranyai államhatár a $X X$. században (The state border in Baranya county in the $20^{\text {th }}$ century). Budapest, HM Hadtörténeti Intézet és Múzeum.

Houellebecq, M. 2015. Behódolás (Submission). Budapest, Magvető.

Kertész, I. 2014. A végső kocsma (The last pub). Budapest, Magvetö.

Kocsis, K., Molnár Sansum, J., Kreinin, L., Michalkó, G., BotTlik, Zs., Szabó, B., Balizs, D. and VArga, GY. 2016. Geographical characteristics of contemporary international migration in and into Europe. Hungarian Geographical Bulletin 65. (4): 369-390.

Kolossov, V. 2005. Border studies: Changing perspectives and theoretical approaches. Geopolitics 10. (4): 606-632.

LAINE, J.P. 2016. The multiscalar production of borders. Geopolitics 21. (3): 465-482.

Lasswell, H.D., Leites, N., FAdner, R., Goldsen, J.M., Grey, A., Janis, I.L., Kaplan, A., Kaplan, D., Mintz, A., De Sola Pool, I. and YaKobson, S. 1949. Language of politics: Studies in Quantitative Semantics. New York, G.W. Stewart Publishers.

Newman, D. 2006a. The lines that continue to separate us: borders in our 'borderless' world. Progress in Human Geography 30. (2): 143-161.

Newman, D. 2006b. The resilience of territorial conflict in an era of globalization. In Territoriality and conflict in an era of globalization. Eds.: KAHLER, M. and WALTER, B., Cambridge, Cambridge University Press, 85-110.

Newman, D. 2011. Contemporary research agendas in border studies: An overview. In The Ashgate research companion to border studies. Ed.: WastL-Walter, D., Farham, Ashgate, 33-48.

Newman, D. and PaAsi, A. 1998. Fences and neighbours in the postmodern world: boundary narratives in political geography. Progress in Human Geography 22. (2): 186-207.

O'DowD, L. 2002. The changing significance of European borders. Regional E Federal Studies 12. (4): 13-36.
OAKESHOTT, M. 199. Rationalism in politics and other essays. Indianapolis, Liberty Fund.

Olay, F. 1930. Csonka-Magyarország határairól (On the borders of Mutilated-Hungary). Budapest, Franklintársulat.

PAASI, A. 2011. A border theory: An unattainable dream or a realistic aim for border scholars? In The Ashgate research companion to border studies. Ed.: WASTL-WALTER, D., Farham, Ashgate, 11-32.

PAP, N. and Glied, V. 2017a. The Hungarian border barrier and the Islam. Journal of Muslims in Europe 6. (1): 104-131.

PAp, N. and Glied, V. 2017b. The ideology of the Hungarian radical right-wing party, the Jobbik and Islam. Europe-Asia Studies (accepted for publication).

Pap, N., Reményi, P., M. Császár, Z. and Végh, A. 2014. Islam and the Hungarians. Mitteilungen der Österreichischen Geographischen Gesellschaft 156. 191-220.

Rónai, A. 1945. Közép-Európa atlasz/Atlas of Central Europe. Budapest-Balatonfüred, Államtudományi Intézet.

Scotт, J.W. 2011. Borders, border studies and EU enlargement. In The Ashgate research companion to border studies. Ed.: WAstl-WALter, D., Farham, Ashgate, 123-142.

Scott, J.W. and van Houtum, H. 2009. Reflections on EU territoriality and the 'bordering' of Europe. Guest editorial. Political Geography 28. (5): 271-273.

Sík, E., Simonovits, B. and SzeitL, B. 2016. Az idegenellenesség alakulása és a bevándorlással kapcsolatos félelmek Magyarországon és a visegrádi országokban (The evolution of xenophobia and the fears about immigration in Hungary and in the Visegrad countries). Regio 24. (2): 81-108.

Simonovits, B. and Szalai, B. 2013. Idegenellenesség és diszkrimináció a mai Magyarországon (Xenophobia and discrimination in contemporary Hungary). Magyar Tudomány 174. (3): 251-262.

SoHn, C. 2014. Modelling cross-border integration: the role of borders as a resource. Geopolitics 19. (3): $587-608$

Swartz, D.L. 2013. Symbolic Power, Politics, and Intellectuals. Chicago, The University of Chicago Press.

SzÁrAz, O. 2012. A kereszténység védőbástyája (Defending bastion of Christianity). Studia litteraria 50. (1-2): 51-67.

Timár, J. 2007. Határtalan határok: a határok, mint társadalmi konstrukciók (Borderless boundaries: borders as social constructions). In Határkonstrukciók magyar-szerb vizsgálatok tükrében. Ed.: Tiмár, J., Békéscsaba, ARI Békéscsaba Department, Centre for Regional Studies, MTA, 70-80.

van Houtum, H. 2011. The mask of the border. In The Ashgate research companion to border studies. Ed. Wastl-Walter, D., Farham, Ashgate, 49-62.

van Houtum, H. and van Naerssen, T. 2002. Bordering, ordering and othering. Tijdschrift voor Economische en Sociale Geografie 93. (2): 125-136. 